\title{
Are trawl marks a good indicator of trawling pressure in muddy sand fishing grounds?
}

\author{
Mérillet Laurène ${ }^{1}$, Kopp Dorothée ${ }^{1,{ }^{*}}$, Robert Marianne ${ }^{1}$, Salaün Michele ${ }^{1}$, Méhault Sonia ${ }^{1}$, \\ Bourillet Jean-Francois ${ }^{2}$, Mouchet Maud ${ }^{3}$
}

${ }^{1}$ Ifremer, Unité de Sciences et Technologies Halieutiques, Laboratoire de Technologie et Biologie Halieutique (LTBH), 8 rue François Toullec, 56100 Lorient, France

2 Ifremer, département Ressources physiques et Ecosystèmes de fond de Mer (REM), Centre de Bretagne, Zl de la Pointe du Diable, CS 10070, 29280 Plouzané, France

${ }^{3}$ UMR 7204 MNHN-UPMC-CNRS Centre d'Ecologie et de Sciences de la Conservation (CESCO), 43 rue Buffon, 75005 Paris, France

* Corresponding author : Laurène Mérillet, email address : laurene.merillet@gmail.com

\begin{abstract}
:
The development of the vessel monitoring system (VMS) in the recent years has offered high-resolution data to map the distribution and intensity of fishing activities and contributed to enhancing the potential identification of fishing impacts. However, impacts could vary at very small scale and the resolution of VMS data might not be fine enough. Other proxy could be used, such as trawl marks visible on the seabed observed by underwater video or side-scan sonar to evaluate small-scale trawling effort. In the Bay of Biscay, an underwater video survey of the Nephrops norvegicus fishing ground was conducted and provided environmental characteristics such as depth and number of trawl marks at 152 transects. The relevance of observed trawl marks as a small-scale proxy of trawling effort was tested depending on the sediment type. The model showed a significant positive relation between density of marks and trawling effort for all sediments together but a different relation for each sediment type. Considering each sediment type separately, the unexpected high number of marks observed on sands could be linked with cohesive interactions between calcium carbonates particles while the low number of marks on fine lithoclastic muds could be due to sediment reworking and bioturbation. We conclude that the impact of trawling on the seabed varies with the type of sediments, hydrodynamic parameters, bioturbation and trawling intensity, leading to a very complex relationship. Trawl marks observed on video footage thus could be used as a proxy of trawling effort among the same type of sediment and not for fine lithoclastic muds.
\end{abstract}




\section{Highlights}

- Trawl marks on the sea bottom were counted with underwater video. Short and long time frame trawling effort assessment were considered. The link between marks and trawling effort is weak. The relation depends on sediments through particle size or calcium carbonate content.

Keywords : Bay of Biscay, Fishing intensity, Sediments, Underwater video, Vessel monitoring system 


\section{Introduction}

The Ecosystem Approach to Fisheries calls for an assessment of fishing impacts on seabed communities in order to maintain ecosystem functioning. In particular, the European Marine Strategy Framework Directive, through descriptor 6, focuses on seafloor integrity and highlights the need for indicators of pressures and state for marine management (Rijnsdorp et al., 2016; Eigaard et al., 2016b). Over the last decade, numerous advances have been made, particularly the improvement in technologies to measure physical impacts (underwater video and side-scan or multi beam sonar) or the access to high-resolution fishing effort information through VMS data (Skaar et al., 2011). Although the VMS data makes it possible to map fishing effort quite efficiently, the recommended resolution of 0.05 degrees $\approx 6 \mathrm{~km}$ (ICES, Advice, September 2014) might be too coarse to be linked to benthos data, collected at the 100-m scale (Skaar et al., 2011; Lambert et al., 2012), leading to a spatial mismatch between patterns of fishing effort and benthic biodiversity. Attempts to solve this issue were made through an increase in resolution of VMS data (Lambert et al., 2012) or the simultaneous use of several complementary devices such as video and sonar to observe trawl marks on the seabed (Humborstad et al., 2004; Smith et al., 2007; Malik and Mayer, 2007). The relation between trawling effort and trawl marks observed with video or sides-can sonar was also investigated (Krost et al., 1990; Friedlander et al., 1999; Buhl-Mortensen et al., 2016), highlighting the interest in such devices to evaluate fishing effort at fine scale. In 2014, an underwater video survey was conducted in the Nephrops fishing ground of the Bay of Biscay known as the "Grande Vasière". These video recordings notably allowed the marks left by the otter trawl doors to be counted. Fishing effort was mapped based on VMS data, but the potential use of trawl marks as a useful indicator to evaluate trawling effort at a fine scale was questioned. In review of trawling impacts on the seabed, Linnane et al. (2000) reported that trawl doors might cause more or less distinct marks according to the sediment 
type and characteristics of the fishing gear. Different authors have observed highly variable delays before the disappearance of these marks from the continental shelf: from several hours (Margetts and Bridger, 1971, cited in Linnane et al., 2000) to a year (Schwinghamer et al., 1998) while on the deep seafloor, they could remain longer than 50 years (Dyment et al., 2014).

Here, we made a comparison between trawling effort estimated with VMS data and the observed marks, accounting for sediment type. Since no information was available about the persistence of trawl marks on the different sediment types considered in our study, two time frames were used for trawling effort: a short one corresponding to the week before the survey and a longer one of 4 months, corresponding to the whole Nephrops fishing season.

\section{Material and methods}

The area studied is $225 \mathrm{~km}$ long by $40 \mathrm{~km}$ wide and lies in the north-east Bay of Biscay, France (Fig. 1) (Bourillet et al., 2006). The sampling sites were located on the continental shelf at depths ranging from $66 \mathrm{~m}$ to $133 \mathrm{~m}$. In September 2014, 152 video transects were realized on board of the R/V Celtic Voyager. Their locations were chosen along a regular square grid of $8.7 \times 8.7 \mathrm{~km}$ resolution, built from a first point picked randomly inside the limits of the study area. A camera was fixed on a sledge dropped onto the seabed and towed for a 10 min haul at an average speed of 0.85 knots (methodology developed by Lordan et al., 2011). Transects were, on average, $183.7 \mathrm{~m}$ long for a filmed area of $143.9 \mathrm{~m}^{2}$ (for more details see Merillet et al., 2017).

Twin and single otter trawls account for the major part of fishing effort in the Grande Vasière ( $89.7 \%$ of the total fishing hours over the period considered here). Otter trawl doors are the part of the gear that has the strongest impact on the seabed (Eigaard et al., 2016a) whose most visible sign being marks in the sediment. In this study, a trawl mark was defined as the linear 
depression of circa $5 \mathrm{~cm}$ deep and 15-20 $\mathrm{cm}$ width, dug by one door. Every visible track (hereafter named trawl marks) on the video footage, crossing the course of the sledge, was counted. With underwater video, it is impossible to find out which door tracks were paired, i.e. which door tracks result of the 2 doors of one trawl. At the exception of some turbidity clouds, images of the seabed were clear. The number of observed trawl marks was summed for each transect and divided by the sampled area to get a homogenized measure of the number of trawl marks per $\mathrm{m}^{2}$ (hereafter referred to as density of marks).

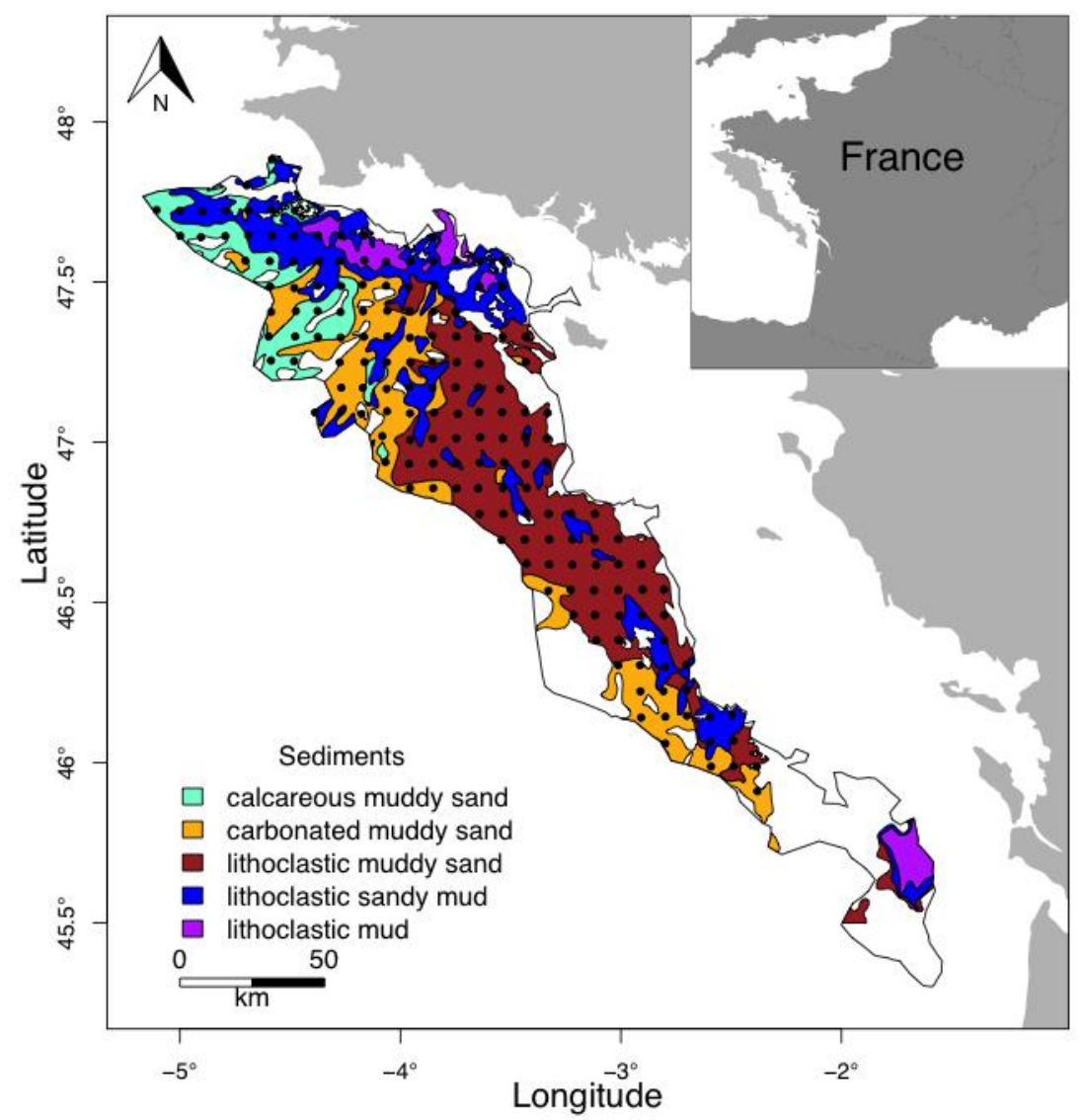

Figure 1: Map of the sampling area. Black dots indicate transects.

VMS effort data were obtained from the French Direction of Maritime Fisheries (DPMA) and processed using the SACROIS algorithm (Demaneche et al., 2010) at a resolution of 3' $\times 3$ '. For the long time frame, fishing hours were summed in each grid cell over 26 weeks from the beginning of April to the end of September 2014, which corresponds to the Nephrops fishing season, when most trawling activity takes place in the Grande Vasière. To account for the potential rapid disappearance of marks, a short time frame trawling effort assessment was 
made, based on the week before the sampling campaign. The type of sediments at each sampling site was obtained from Bouysse et al. (1986) (Table 1).

Table 1: Sediment type classification, modified from Bouysse et al. (1986) who had classified them according to their grain size (percentage of silt and clay particles, i.e. particles smaller than $63 \mu \mathrm{m}$, varying from sand to mud) and calcium carbonate content (between $10 \%$ and $30 \%$, between $30 \%$ and $50 \%$ or $>50 \%$ ). The percentage of total number of station and the area of each sediment type is in parenthesis. For more clarity, the correspondence with Folk's classification is given.

\begin{tabular}{|c|c|c|c|c|c|}
\hline & & \multicolumn{4}{|c|}{ Grain size } \\
\hline & & fine $<25 \%$ & $25 \% \leq$ fine $<50 \%$ & $50 \% \leq$ fine $<75 \%$ & fine $\geq 75 \%$ \\
\hline \multirow{3}{*}{$\begin{array}{l}\text { Calcium } \\
\text { carbo- } \\
\text { nate } \\
\text { content }\end{array}$} & $10 \% \leq$ calcium carb. $<30 \%$ & $\begin{array}{c}\text { Lithoclastic muddy sand } \\
(39.5 \% \text { of transects - } \\
\left.4666 \mathrm{~km}^{2}\right)\end{array}$ & \multicolumn{2}{|c|}{$\begin{array}{c}\text { Lithoclastic sandy mud } \\
\left(22.4 \% \text { of transects }-2692 \mathrm{~km}^{2}\right)\end{array}$} & $\begin{array}{c}\text { Lithoclastic mud } \\
\text { (3.9\% of transects } \\
\left.-633 \mathrm{~km}^{2}\right)\end{array}$ \\
\hline & $30 \% \leq$ calcium carb. $<50 \%$ & $\begin{array}{c}\text { Carbonated muddy sand } \\
(23.7 \% \text { of transects - } \\
\left.2537 \mathrm{~km}^{2}\right)\end{array}$ & & & \\
\hline & calcium carb. $\geq 50 \%$ & $\begin{array}{c}\text { Calcareous muddy sand } \\
(10.5 \% \text { of transects - } \\
\left.1153 \mathrm{~km}^{2}\right) \\
\end{array}$ & & & \\
\hline \multicolumn{2}{|c|}{ Folk's classification correspondence } & Sand & Muddy sand & Sandy mud & Mud \\
\hline
\end{tabular}

The trawling effort (fishing hours) was plotted by sediment type for the two time frames. A non-parametric Kruskal-Wallis multi-comparison (Siegel and Castellan post-hoc test) was performed to distinguish significant pairwise differences in trawling effort between sediment types, to identify sediment types more prone to exhibiting trawl marks. Similarly, trawl marks were plotted and a Kruskal-Wallis multi-comparison was performed to compare the density of marks observed on each sediment type. We then tested the effect of trawling effort and sediment type on the density of marks using a zero-inflated negative binomial model to handle the number of zeros (trawl mark density had $82.2 \%$ zeros) and the uncertainty in the origin of these zeros (i.e. true or false zeros depending on whether the mark was truly absent or just not detected). The zero-inflated model models the distribution of excess zeros separately from count data, which are modelled in the count model (Table 1). 


\section{Results and discussion}

In both the short and long time frames, trawling effort intensity was different between sediment types. The highest trawling effort was exerted over lithoclastic sandy mud and lithoclastic muds (Fig. 2.A and 2.B). Trawling effort was the lowest over calcareous muddy sands for the long time frame (Fig. 2.A) and over carbonated muddy sands for the short time frame (Fig. 2.B). The density of observed trawl marks was not significantly different between sediment types (Fig. 2.C.).
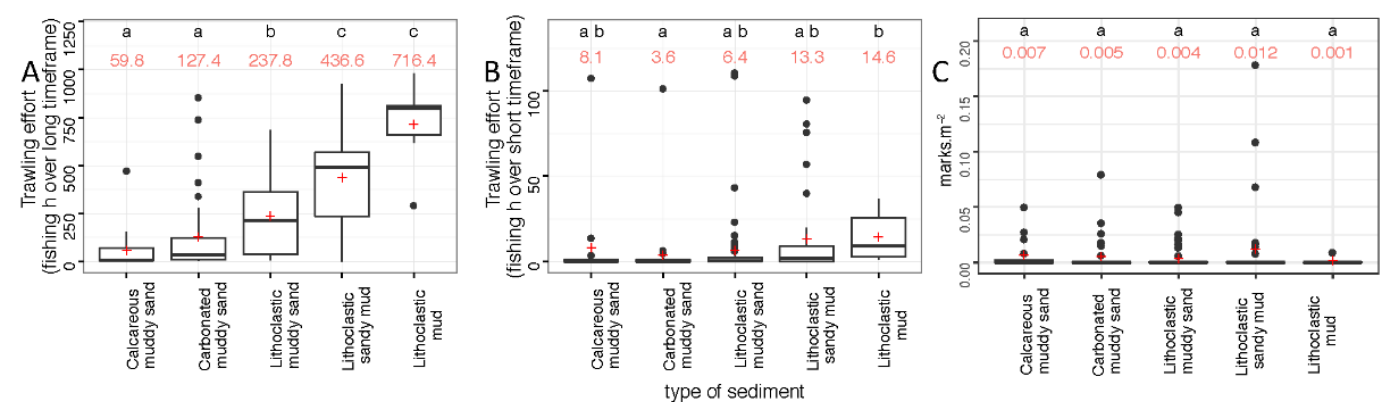

Figure 2: Boxplot of trawling effort for the long time frame (A), short time frame (B) and trawl marks. $\mathrm{m}^{-2}(\mathrm{C})$, on each sediment type. Black dots represent sampling sites. The "+" indicates the mean, whose value is given on the top of the boxplot for each sediment type. A letter indicates the result of the Kruskal-Wallis multi-comparison (Siegel and Castellan post hoc test): if at least one letter is the same between two sediment types, there is no pairwise significant difference between the means for these two sediment types.

For the short time frame, according to the zero-inflated model, the log odds of observing zero marks due to false zero decreased significantly as trawling effort increased (Table 2.A.). No such significant relation was observed for the long time frame (Table 2.A.).

The count models showed a significant positive relation between the density of marks and the trawling effort for both short and long time frames (Table 2.B) For the long timeframe, the density of marks was significantly lower in lithoclastic muds (Table 2.B.). When looking at the predicted number of marks from the models at each sampling site for the long time frame (Fig. 3.A.), the highest mean number of marks was predicted for the lithoclastic sandy muds (1.85 predicted marks per transect), calcareous muddy sands (1.10 predicted marks per 
transect) and carbonated muddy sands (0.72 predicted marks per transect). The lowest predicted number of marks was on lithoclastic muds ( 0.17 predicted marks per transect). The result was very similar for the short time frame (Fig. 3.B).

Table 2: Summary of the zero-inflated negative binomial models. Significant $p$-values $\leq 0.05$ are in bold.

\begin{tabular}{|c|c|c|c|c|c|c|c|c|}
\hline & \multicolumn{4}{|c|}{ Long time frame } & \multicolumn{4}{|c|}{ Short time frame } \\
\hline & Estimate & Std error & Z scores & p-value & Estimate & Std error & Z scores & p-value \\
\hline \multicolumn{9}{|c|}{ (A) Zero inflation model coefficients } \\
\hline Intercept & -4.06 & 0.68 & -5.99 & $2.07 \mathrm{e}^{-9}$ & -3.92 & 0.70 & -5.6 & $2.04 \mathrm{e}^{-8}$ \\
\hline Trawling effort & $-1.62 \mathrm{e}^{-3}$ & $1.19 \mathrm{e}^{-3}$ & -1.36 & 0.17 & -0.03 & 0.01 & -2.64 & 0.01 \\
\hline Carbonated muddy sand & 0.54 & 0.86 & 0.63 & 0.53 & 0.40 & 0.85 & 0.47 & 0.64 \\
\hline Lithoclastic muddy sand & 0.89 & 0.84 & 1.05 & 0.29 & 0.67 & 0.80 & 0.84 & 0.40 \\
\hline Lithoclastic sandy mud & 1.17 & 0.95 & 1.23 & 0.22 & 0.70 & 0.84 & 0.83 & 0.41 \\
\hline Lithoclastic mud & -9.79 & 675.65 & -0.01 & 0.99 & -0.75 & 3.21 & -0.23 & 0.82 \\
\hline \multicolumn{9}{|c|}{ (B) Count model coefficients } \\
\hline Intercept & -3.99 & 0.49 & -8.11 & $5.23 \mathrm{e}^{-16}$ & -3.94 & 0.47 & -8.332 & $<2.00 . \mathrm{e}^{-16}$ \\
\hline Trawling effort & $2.68 \mathrm{e}^{-3}$ & $1.18 \mathrm{e}^{-3}$ & 2.27 & $2.31 \mathrm{e}^{-2}$ & 0.01 & $4.78 \mathrm{e}^{-3}$ & 2.24 & 0.03 \\
\hline Carbonated muddy sand & -0.65 & 0.71 & -0.91 & 0.36 & -0.12 & 0.62 & -0.19 & 0.85 \\
\hline Lithoclastic muddy sand & -1.02 & 0.72 & -1.42 & 0.16 & -0.216 & 0.585 & -0.37 & 0.71 \\
\hline Lithoclastic sandy mud & -0.39 & 0.83 & -0.46 & 0.65 & 0.49 & 0.60 & 0.82 & 0.41 \\
\hline Lithoclastic mud & -4.67 & 1.48 & -3.16 & $1.56 \mathrm{e}^{-3}$ & -2.30 & 1.66 & -1.38 & 0.17 \\
\hline $\log ($ theta $)$ & 0.59 & 0.64 & 0.93 & 0.35 & 0.66 & 0.62 & 1.07 & 0.29 \\
\hline
\end{tabular}

The relation between predicted marks and trawling intensity is different for each sediment type (Fig. 3). Counter-intuitively, the lowest density of marks was observed in the heavily trawled areas (i.e., those with lithoclastic muds), while areas with calcareous and carbonated muddy sands had among the lowest trawling efforts but the highest density of marks (Fig. 2 and Fig. 3). Carbonated and calcareous muddy sands thus tend to maintain visible trawl marks. Conversely, lithoclastic muds are not marked or the marks disappear quickly on this sediment type. Finally, more intuitively, lithoclastic sandy muds had the second highest trawling effort, showed the highest density of marks observed (Fig. 2) and also had among the highest number of marks predicted for each sampling site (Fig. 3). 

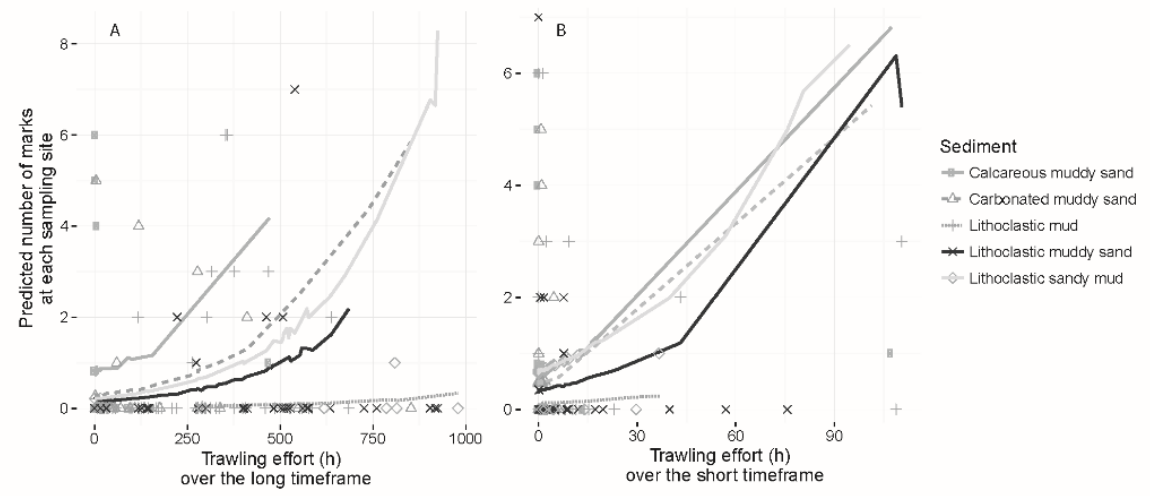

Figure 3: Trend between trawl marks and trawling effort, for the long time frame (A) and short time frame (B) according to sediment type. Points are the observed number of trawl marks. Curves are the number of trawl marks predicted from zeroinflated models.

Differences in the relation between trawl marks and trawling intensity across sediment types might be explained by some of their physical properties, such as grain size (mud, sandy mud or muddy sand), or by chemical links between particles (due to the fine carbonate fraction or the fine particles). The degree of penetration of the trawl doors into the sediment as well as resuspension have been proven to depend on the grain size, with deeper penetration and more resuspension on finer muddy sediments than the coarser sandy ones (Linnane et al., 2000; Humborstad et al., 2004; Oberle et al., 2015). The resuspended sediments might then cover and erase the tracks (Friedlander et al., 1999). Doors penetration also depends on cohesive strength between particles. For instance, calcium carbonate and clay particles are linked by mechanical and chemical links stronger than those among lithoclastic sand particles, which leads to a higher shear stress resistance of the sediment as the calcium carbonate content increases (Lee, 1982). The higher trawl mark persistence on carbonated and calcareous muddy sands could therefore stem from these cohesive strengths between the particles.

Several hypotheses could explain the low density of trawl marks observed on lithoclastic muds compared to what might be expected from the intensity of trawling effort. First, lithoclastic muds are superficially penetrated by trawl doors and are four times less 
resuspended than muds with a lower clay fraction (Oberlé et al., 2015), most likely because of high cohesive forces between clay particles. Frequent trawling could also have resuspended fine particles, then taken away by current (Mengual et al., 2016), which would lead to a compaction and sediments, less prone to mark. A more likely explanation could be the reworking of the seabed due to the high trawling frequency over this type of sediment. The frequent ploughing by the doors on lithoclastic muds might have resulted in a less compact seabed, more prone to quick disappearance of marks as well as the resuspension of sediments, which settled on the marks and erased them. Besides, lithoclastic muds are located on the shallowest areas, exposed to tidal currents or wave actions that erase the marks. Finally, a high bioturbation activity, suggested by the high density of Nephrops, Munida and Goneplax burrows observed on lithoclastic muds, could also be responsible for surface sediment mixing $(5-20 \mathrm{~cm})$ thereby contributing to the erasure of trawl mark over the long-time frame (Schwinghamer et al., 1998; Mengual et al., 2016). More generally, marks could disappear due to hydrodynamic parameters such as current or water movements during storm, sweeping by trawl nets, natural sedimentation or sedimentation of resuspended sediments (Friedlander et al., 1999; Linnane et al., 2000).

\section{Conclusion}

The seafloor of the Grande Vasière is constituted for $95 \%$ by sand, muddy sand or sandy mud and for $5 \%$ by mud. The trawling effort obtained from VMS data at a relatively low resolution $\left(3^{\prime} \times 3^{\prime}\right)$ and trawl marks observed on underwater video footage are spatially congruent over $95 \%$ of the area. The model showed a significant positive relation between density of marks and trawling effort for all sediment together. However, the relation between predicted marks and trawling intensity is different for each of the 5 sediment types in this study. In particular, lithoclastic muds have to be considered separately since it showed a very small slope in the 
relation between predicted marks and intensity. Indeed, the higher fishing effort coincides with the lowest density of trawl marks on this sediment.

The relation between trawl marks and trawling effort could depends on the mechanical (i.e., grain size) and chemical (i.e., calcium carbonate content) characteristics of the sediment type but also on the intensity of the fishing effort. This complexity is further increased by bioturbation and hydrodynamic parameters that are likely uneven across time and space, which may contribute to a variable durability of trawl marks over time (Mengual et al., 2016). Considering all these factors, using trawl marks from video recordings as a fine-scale proxy of fishing effort is relevant for each sediment type taken separately, except on lithoclastic muds. Knowing the distribution of trawl marks at very fine-scale could provide useful information for the conservation of vulnerable species at local scale by accounting for the patchiness of trawling effort better than VMS data (Buhl-Mortensen et al., 2016; Eigaard et al., 2016b; Merillet et al., 2017). For a comprehensive assessment, underwater video could be completed by sonar, which can identified old marks no longer visible on video footage, even in turbid waters (Malik and Mayer, 2007; Smith et al., 2007).

\section{Acknowledgements}

Trawl marks data were acquired during the TETRIS project funded by IFREMER and France Filière Pêche. The authors gratefully acknowledge the French DPMA who provided the VMS data and the team of the SIH (French fisheries information system) who processed it. VMS data were processed such that the identity of vessels was masked. Authors also thank the LANGOLF-TV team for video acquisition, the staff of the R/V Celtic Voyager and the Marine Institute of Ireland for their contribution to the data collection, and the CNPMEM. This note benefitted greatly from information provided by B. Mengual and P. Le Hir (IFREMER-DYNECO). 


\section{References}

Bourillet, J-F., Jouanneau, J-M., Macher, C., Le Hir, P., Naughton, F., 2006. "La Grande Vasière" mid-shelf mud belt: Holocene sedimentary structure, natural and anthropogenic impacts. X International Symposium on Oceanography of the Bay of Biscay, Vigo, Spain, April 19-21 2006, pp. 131-134.

Bouysse, P., Lesueur, P., Klingebiel, A., 1986. Carte des sédiments superficiels du plateau continental du Golfe de Gascogne - Partie septentrionale au 1/500.000. BRGM/ IFREMER.

Buhl-Mortensen, L., Ellingsen, K.E., Buhl-Mortensen, P., Skaar, K.L., Gonzalez-Mirelis, G., 2016. Trawling disturbance on megabenthos and sediment in the Barents Sea: chronic effects on density, diversity, and composition. ICES J. Mar. Sci. 73, 98-114. doi:10.1093/icesjms/fsv200

Demaneche S., Begot E., Gouello A., Habasque J., Merrien C., Leblond E., Berthou P., Harscoat V., Fritsch M., Leneveu C., Laurans M., 2010. Projet SACROIS "IFREMER/DPMA" - Rapport final - Convention SACROIS 2008-2010. URL http://sih.ifremer.fr/Description-des-donnees/Donnees-estimees/SACROIS

Dyment, J., Lallier, F., Le Bris, N., Rouxel, O., Sarradin, P.-M., Lamare, S., Coumert, C., Morineaux, M., Tourolle, J., 2014. Les impacts environnementaux de l'exploitation des ressources minérales marines profondes. Expertise scientifique collective.

(Environmental impacts of deep sea mining. Collective scientific expertise.). Synthèse du rapport, CNRS - Ifremer, 110p.

Eigaard, O.R., Bastardie, F., Breen, M., Dinesen, G., Hintzen, N.T., Laffargue, P., Mortensen, L.O., Nielsen, J.R., Nilsson, H.C., O’Neill, F.G., Polet, H., Reid, D.G., Sala, A., Sköld, M., Smith, C., Sorensen, T.K., Tully, O., Zengin, M., Rijnsdorp, A., 2016a. Estimating 
seabed pressure from demersal trawls, seines, and dredges based on gear design and dimensions. ICES J. Mar. Sci. 73, 27-43.

Eigaard, O., Bastardie, F., Hintzen, N., Buhi-Mortensen, L., Buhi-Mortensen, P., Catarino, R., Dinesen, G., Eqevist, J., Fock, H., Geitner, K., Gerritsen, H., Marin, M., Jonsson, P., Kavadas, S., Laffarque, P., Lundy, M., Gonzalez-Mirelis, G., Nielsen, J.R., Papadopoulou, N., Smith, C., Posen, P., Pulcinella, J., Russo, T., Sala, A., Silva, C., Vanelslander, B., Rijnsdorp, A., 2016b. The footprint of bottom trawling in European waters: distribution, intensity and seabed integrity. ICES J. Mar. Sci. 74, 847-865.

Friedlander, A.M., Boehlert, G.W., Field, M.E., Mason, J.E., Gardner, J. V., Dartnell, P., 1999. Sidescan-sonar mapping of benthic trawl marks on the shelf and slope off Eureka, California. Fish. Bull. 97, 786-801.

Humborstad, O.B., Nottestad, L., Lokkeborg, S., Rapp, H.T., 2004. RoxAnn bottom classification system, sidescan sonar and video-sledge: Spatial resolution and their use in assessing trawling impacts. ICES J. Mar. Sci. 61, 53-63.

ICES. 2014. General advice - OSPAR request on mapping of bottom fishing intensity using VMS data. Special request, Advice September 2014. Version 2, 26-09-2014.

Lambert, G.I., Jennings, S., Hiddink, J.G., Hintzen, N.T., Hinz, H., Kaiser, M.J., Murray, L.G., 2012. Implications of using alternative methods of vessel monitoring system (VMS) data analysis to describe fishing activities and impacts. ICES J. Mar. Sci. 69, $682-693$.

Lee, H.J., 1982. Bulk density and shear strength of several deep-sea calcareous sediments. Geotechnical properties, behaviour and performance of calcareous soils, ASTM STP 777. K.R. Demars and R.C. Chaney Eds., American Society for Testing and Materials, pp.54-78. 
Linnane, A., Ball, B., Munday, B., van Marlen, B., Bergman, M., Fonteyne, R., 2000. A review of potential techniques to reduce the environmental impact of demersal trawls. Irish Fish. Investig. 43 pp.

Lordan, C., Doyle, J., Bunn, R., Fee, D., Allsop, C., 2011. Aran, Galway Bay and Slyne Head Nephrops Grounds (FU17) 2011 UWTV Survey Report. Marine Institute, Galway.

Malik, M.A., Mayer, L.A., 2007. Investigation of seabed fishing impacts on benthic structure using multi-beam sonar, sidescan sonar, and video. ICES J. Mar. Sci. 64, 1053-1065.

Margetts, A.R., Bridger, J.P., 1971. The effect of a beam trawl on the sea bed. ICES C.M. 1971/B:8, 9 pp.

Mengual, B., Cayocca, F., Le Hir, P., Draye, R., Laffargue, P., Vincent, B., Garlan, T., 2016. Influence of bottom trawling on sediment resuspension in the "Grande-Vasière" area (Bay of Biscay, France). Ocean Dyn. 66, 1181-1207.

Merillet, L., Mouchet, M., Robert, M., Salaün, M., Schuck, L., Vaz, S., Kopp, D., 2017. Using underwater video to assess megabenthic community vulnerability to trawling in the Grande Vasière (Bay of Biscay). Environ. Conserv. 1-10.

Oberle, F.K.J., Storlazzi, C.D., Hanebuth, T.J.J., 2015. What a drag: Quantifying the global impact of chronic bottom trawling on continental shelf sediment. J. Mar. Syst. 159, 109119.

Rijnsdorp, A.D., Bastardie, F., Bolam, S.G., Buhl-Mortensen, L., Eigaard, O., Hamon, K.G., Hiddink, J.G., Hintzen, N.T., Ivanovic, A., Kenny, A., Laffargue, P., Nielsen, J.R., O’Neill, F.G., Piet, G.J., Polet, H., Sala, A., Smith, C., van Denderen, P.D., Van Kooten, T., Zengin, M., 2016. Towards a framework for the quantitative assessment of trawling impact on the seabed and benthic ecosystem. ICES J. Mar. Sci. 73, 127-138.

Schwinghamer, P., Gordon, D.C., Rowell, T.W., Prena, J., Mckeown, L., Sonnichsen, G., Guigné, J.Y., 1998. Effects of experimental otter trawling on surficial sediment 
properties of a sandy-bottom ecosystem on the Great Banks of Newfoundland. Conserv. Biol. 12, 1215-1222.

Skaar, K.L., Jørgensen, T., Ulvestad, B.K.H., Engås, A., 2011. Accuracy of VMS data from Norwegian demersal stern trawlers for estimating trawled areas in the Barents Sea. ICES J. Mar. Sci. 68, 1615-1620.

Smith, C.J., Banks, A.C., Papadopoulou, K.N., 2007. Improving the quantitative estimation of trawling impacts from sidescan-sonar and underwater-video imagery. ICES J. Mar. Sci. 64, 1692-1701. 
Supplementary data for: Are trawl marks a good indicator of trawling pressure in muddy sand fishing grounds?

Laurène Mérillet* ${ }^{1}$, Dorothée Kopp ${ }^{1}$, Marianne Robert ${ }^{1}$, Michèle Salaün ${ }^{1}$, Sonia Méhault ${ }^{1}$, Jean-François Bourillet ${ }^{2}$, Maud Mouchet ${ }^{3}$

${ }^{1}$ Ifremer, Unité de Sciences et Technologies Halieutiques, Laboratoire de Technologie et Biologie Halieutique (LTBH), 8 rue François Toullec, F-56100 Lorient, France

${ }^{2}$ Ifremer, département Ressources physiques et Ecosystèmes de fond de Mer (REM), Centre de Bretagne, ZI de la Pointe du Diable, CS 10070, 29280 Plouzané, France

${ }^{3}$ UMR 7204 MNHN-UPMC-CNRS Centre d'Ecologie et de Sciences de la Conservation (CESCO), 43 rue Buffon, CP135, 75005 Paris, France

* Corresponding author: Laurène Mérillet E-mail: laurene.merillet@gmail.com

Pictures of trawl marks in the Grande Vasière. Credits: Julien Simon 


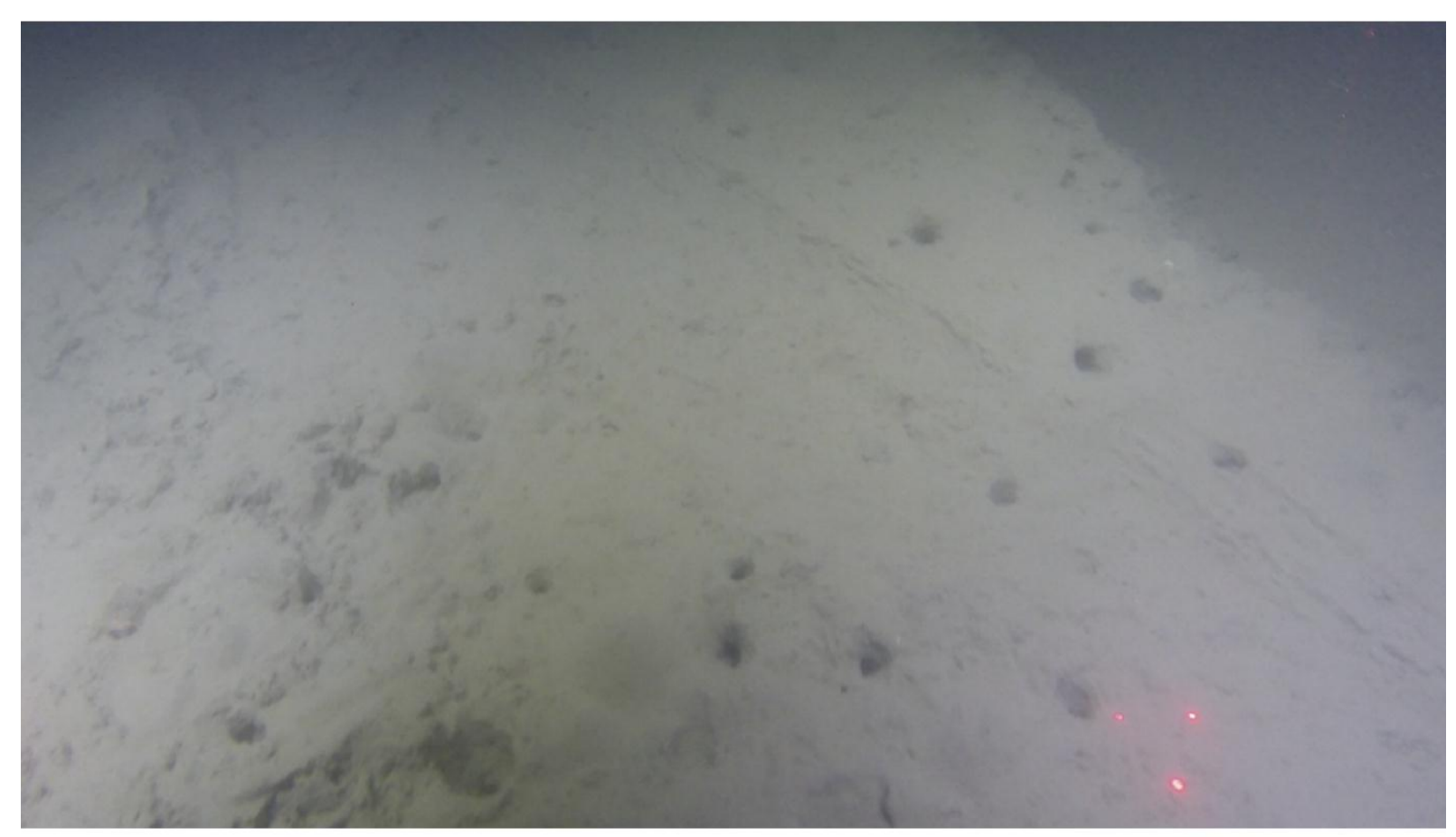

